\title{
Problems Associated with the Legal Substance of Encumbrances on Real Estate and the Related Right of Use
}

\author{
Inga Kudeikina \\ Faculty of Law, Riga Stradinss University, Latvia
}

Copyright $(2016$ by authors, all rights reserved. Authors agree that this article remains permanently open access under the terms of the Creative Commons Attribution License 4.0 International License

\begin{abstract}
Encumbrances on real estate and on the right to use real estate are different legal institutions. Encumbrances that are created on the basis of law have a different legal substance. As a rule, encumbrances by law are significant and bring benefits to an unlimited number of rightholders. This type of encumbrances includes various protection zones, roads, nature reserves, etc. It is assumed that these encumbrances are for the common good; therefore, the rights of an owner may be restricted. Encumbrances on the right to use real estate are of an individual nature, referring to specific rightholders. Such encumbrances include, inter alia, easements and mortgages. In these cases, the owner may not freely dispose of his property right (property), without considering the rights of third parties. The article is devoted to the problems pertaining to the establishment of encumbrances on real estate. Encumbrances may be established by an agreement between the parties, and legislation allows establishing encumbrances without any authorisation from the real estate owner. The objective of the thesis is to analyse the legitimacy of encumbrances based on law in the context of the impairment of owner's property rights.
\end{abstract}

Keywords Encumbrances, Restrictions on Property Rights, Compensation

\section{Introduction}

Real estate has always been an essential element of economic growth. Equally important is the role of real estate in meeting social needs and ensuring public welfare. Real estate allows for the exercise of individual's constitutional rights. For instance, real estate provides housing, healthy and safe environment and a possibility of obtaining material benefits from the property. The Universal Declaration of Human Rights serves as the initial legal base of these principles [1], and, according to this Declaration, everyone has the right to own property and no one shall be arbitrarily deprived of his property, everyone has the right to a standard of living adequate for the health and well-being of himself and of his family, including food, clothing, housing and medical care and necessary social services. Democratic countries have implemented these principles into their national laws. Chapter VIII of the Latvian Constitution contains provisions safeguarding fundamental human rights [2].

The path of public development testifies to the approximation of various social and economic processes. Population growth leads to the decrease in isolation and aloofness. Nowadays, the necessity for cooperation is an objective fact. This also refers to the utilisation of properties, which is most often outside the needs of a single owner and the boundaries of a single property, for instance, ensuring of the construction and maintenance of public roads and technical facilities (gas pipelines, communications and power supply equipment), flora and fauna protection. It is evident that this manner of utilisation concerns the needs of the entire society or at least communities of certain regions rather than individual owners. The socially responsible exercise of own rights is coming to the foreground. The partial restriction on an individual's rights for the common good is reflected in legal doctrine. The author shares the opinion of Martijn W. Hesselink, Professor of the Amsterdam Institute for Private Law, that "private law is no longer based on the principle of autonomy" [3, 283]. This means that legal scholars and society in general face a new challenge, which is to find a balance between the socially responsible policy of property utilisation and the guaranteeing of an owner's rights.

The establishment of encumbrances is a way to safeguard public interests, which would enable the use of real estate owned by another person for the common good.

Encumbrances on the right to use ownership established for the benefit of a certain person play a no less important role in the maintenance of social balance. As a result, the parties concerned may take full advantage of opportunities 
provided by real estate. For instance, in the case of a mortgage, the owner may use his property to obtain a loan, while the mortgagee is provided with security and a guarantee that his claim will be met in the case of a borrower's default. This form of legal relationships establishes legal security because each party has specific and foreseeable rights and obligations defined by law.

In this article, the author analyses encumbrances as a legal institution, legal aspects of encumbrances and the need for effective mechanisms to safeguard the rights of owners. Encumbrances are established with regard to real estate, i.e., land, regardless of its ownership, which means that it may belong either to private owners or to the state or local governments. The legal procedure for establishing and annulling encumbrances represents a major issue in the context of fundamental human rights. This issue is also analysed in scientific literature, which emphasises that the division of public and private rights also impacts on the application of human rights in private relationships. [4, 22] Legal scholars have not performed any in-depth studies of encumbrances as a legal institution so far. However, these aspects are essential because they are related in the most direct manner to individual's fundamental rights, i.e., the right to property and of unimpeded use of the property, and the public right to use natural heritage, considering that land, as a resource, possesses cultural value.

\section{Materials and Methods}

To this end, both descriptive and analytical methods have been employed to analyse the legal grounds for encumbrances and related case-law. The study has relied on both legislation and case-law.

\section{Results}

The results of the study give strong grounds to conclude that a special procedure could be applied to the establishment of encumbrances in situations when those are intended to meet the needs of the entire society or individual communities of certain regions. Like any other encumbrances, those established by law restrict owner's property rights. A real estate encumbrance should be recognised as a restriction on owner's property rights. Certain remedies should be introduced with a view to balancing the rights and interests of the society and the owner and minimising the adverse effects of encumbrances. Such remedies could comprise an owner's right to claim reasonable compensation, challenge the establishment of encumbrances and initiate their annulment.

\section{Discussion}

Legislation does not provide for any uniform definition of the term 'encumbrance'. As a result, this term stands for various legal institutions, such as easement, mortgage, rent, operating restrictions, and protection zones. More generally, an encumbrance means any third party's rights to real estate. The substance and types of encumbrances as a legal institution may be understood by means of the interpretation of law and the analysis of the legal system.

Encumbrances by their grounds can be categorised as follows:

1) arising from private relationships;

2) arising from public relationships.

This division is significant because private and public relationships are based on different principles of law. According to the theory of law, subordination and the rightholder's action restricted to the legal framework are inherent in public law, while private law is predominantly based on the autonomy of a rightholder and the principle whereby everything which is not forbidden by law is allowed. It should also be stressed that this is not the only reason why this division is essential. Certain legal scholars refer to the fact that historical agreements which are contrary to general objectives have not been recognised. [5, 30-31] Today this opinion should be viewed critically because encumbrances are established also in private relationships, although they do not pursue general objectives.

In private law, mortgage, rent and easement should be viewed as encumbrances. The common feature of these legal institutions is the grounds for their establishment, which can be either law, or an agreement, or a court judgment. As a rule, these encumbrances are defined on an individual basis and created with the consent of the party concerned (real estate owner) or at least with his knowledge. For instance, easements are established for the benefit of a particular person (easement in gross) or for a particular property (appurtenant easement), mortgage is registered for a particular property, and it is a specific property that is rented. On certain occasions, the encumbrance may result not only in the restriction on the rights of the party concerned (real estate owner) but, on the contrary, in material benefits for this party, such as rental.

The grounds for terminating these encumbrances are accurately defined by law [6]. For the most part, encumbrances may be terminated by a relevant agreement between the parties and due to the expiry of their term.

As regards encumbrances arising from private law, obligations are normally established between two parties, i.e. the owner and the party in whose favour the encumbrance is created. The party concerned (real estate owner) is aware of the grounds for terminating encumbrances in advance or is allowed to refer to these grounds by law. Certain kinds of encumbrances bring material benefits to the owner, thereby minimising the adverse effects of the encumbrance, i.e. compensating for the restrictions attached to the exercise of property rights. Considering that obligations arising out of encumbrances are established between rightholders, while legal relationships are associated with real estate, the legal 
substance of encumbrances may be characterised as a mixed legal relationship. Property law treats encumbrances as jura in re aliena, while the law of obligations views them as a duty to comply provided for the party concerned.

These encumbrances have only immaterial significance for public interests.

Legal relationships between the parties are determined by a relevant agreement or, if the parties cannot agree, by a court judgment. It should be stressed, however, that the social role of these legal relationships is not large because they concern a small number of rightholders and, therefore, cannot produce a noteworthy impact on public interests. For instance, a right of way, which is an appurtenant easement, leads to a duty of the owner of the servient real estate to grant access to the relevant road. From the viewpoint of civil relationships, it means that legal relationships are established between the property owner and the person for whose benefit the easement has been created, with no other persons involved. Moreover, seeking to ensure proportionality, special mechanisms to safeguard the owner's rights are provided: the choice of the right of way devolves to the bearer of the easement, who must act sparingly to the maximum extent possible; in establishing a right of way, the rights included in it may be restricted in diverse ways; any maintenance and repair of the servient property required for the purposes of an easement must be carried out by the person who uses the easement. [6]

The above is fully supported by the case-law because, as it has been held by the court, easements are not established merely on grounds of convenience to the owner of the dominant real estate and the choice of the option must also consider the interests of the owners of servient properties that may be potentially involved. [7]

Other encumbrances on the use of the property right have a similar legal structure. Namely, it is a tendency towards the minimisation of adverse impacts of encumbrances. For instance, it is laid down in Section 1315 of the Latvian Civil Law that the pledge does not terminate the pledger's title to the relevant property. Pledgers may still possess and use the pledged immovable property. However, in spite of these efforts, the complete balance between the legal interests of the owner and the person for whose benefit encumbrances have been created is hard to achieve, which, in particular, refers to the instances of competition between the principles of law. This conclusion is drawn from the case-law. Liens registered in the Land Register are subject to the principle of legal authenticity; therefore, "when accepting a pledged property, the person must be sure of the authenticity, stability, indisputability and priority of the right acquired". [8] The Senate of the Latvian Supreme Court has held that the principle of authenticity is a priority and, in the event of any disputes, priority must be fully given to the safeguarding of the rights and interests of the person for whose benefit the encumbrance has been created. [9] In spite of the fact that priority is thereby given only to one of the parties concerned, the author supports the court's opinion because the principle of authenticity of land registers is fundamental for the Land
Register as a record of properties and related rights. Any doubts as to the reliability of Land Register entries would cause litigations that would render valueless the principle of the official registration of properties and related rights. The Land Register serves needs of the entire society, and its effective functioning is more vital than the rights of an individual.

Consequently, it should be recognised that encumbrances combined with an effective mechanism that would minimise any restrictions on the rights of the party concerned would ensure social balance and prevent disputes. This approach is the keystone of modern law, which is also mentioned in scientific literature. For instance, the value of legal acts from the sociological viewpoint is based on two pillars: unanimity and conflict preventability $[10,22]$. This means that a certain legal act, which can also prevent a conflict, is accepted by the majority of the public.

Encumbrances that are meaningful for society arise from public law. They could be described as a matter of national interests. These encumbrances represent territories and facilities that are necessary for the safeguarding of significant public interests and the protection and sustainable use of natural resources [11]. Spatial planning is a duty of public authorities, and the owner has only a minor role in introducing encumbrances. According to Section 4(1) of the Spatial Development Planning Law, spatial development must be planned through public participation, while Section 4(4) of this Law provides that the interests of private individuals and public interests must be balanced with sustainable spatial development. [11] The aforementioned Law contains a declaratory provision. There are grounds for criticism of the fact that owners whose properties are subject to encumbrances are not individually involved in the solution of matters, which is also confirmed by the case-law of the Constitutional Court of the Republic of Latvia showing that applications challenging the detail planning of territories have been lodged nine times. [12] In all these cases, the encumbrances have been recognised as proportionate and complying with the Basic Law. The case-law treats spatial planning as legislation. [13] Therefore, no appeals are allowed because laws may not be appealed through courts of general jurisdiction.

Encumbrances are determined by public authorities (the Cabinet, sectoral ministries, planning regions and local governments) by developing spatial planning. A spatial plan is the initial document providing for encumbrances. The next step is the updating of encumbrances and their registration in a relevant property file of the Land Registry. In accordance with Section 41(2) of the Land Registry Law [14], the process takes place directly between two public authorities (the State Land Service and the Land Registry), without the consent of the real estate owner. It should be noted that a decision taken by a judge of the Land Registry Department concerning the registration of actual encumbrances is not subject to appeal.

Annex 2 "Unified Classification of Encumbered Territories and Real Estate Encumbrances" to Cabinet 
Regulation No 61 of 4 February 2014 serves as the legal basis for establishing encumbrances. [15] According to this Annex, there exist the following encumbrances: the coastal protection zone of the Baltic Sea and the Gulf of Riga, surface water body protection zones, protection zones around marshes, territories of state-protected cultural monuments and their protection zones, protection zones around water-supply points, protection zones along streets and motorways, protection zones along railroads, protection zones along electronic communications networks, protection zones around national meteorological and hydrometric gauging stations, protection zones along power grids, protection zones along heating networks, protection zones around hydrotechnical and amelioration constructions and installations, protection zones along water-supply and sewage networks, protection zones around geodetic points, protection zones around technical means of navigation, gas-supply protection zones, protection zones around state-protected facilities and the state border, protection zones around optical telescopes and radio telescopes, protection zones around facilities subject to enhanced sanitary requirements and territories where pollutants have been or could be detected, protection zones around hydrocarbon extraction sites, as well as pipelines, tanks, storage facilities for oil, oil products, hazardous chemicals and chemical products and related refineries and handling companies, petrol stations, special areas of conservation and their zones, windbreaking forest strips, national subsoil blocks, tow-paths, territories subject to construction restrictions specified in spatial development planning documents and territories designated by local governments for public access to public territories.

The establishment of encumbrances is determined by several laws, including the Protection Zone Law [16], the Fishery Law [17], the Law on the Protection of Cultural Monuments [18], while six other laws deal with certain elements of the creation of encumbrances. The analysis of the applicable legislation has revealed that encumbrances are determined only by public authorities based on law or their decisions (administrative acts) without considering the opinion of real estate owners. Disagreement of the real estate owner may not be an obstacle to encumbrances.

This conclusion is drawn from the works of scholars. For instance, Hans Kelsen presumes that the division between private and public law means, as a rule, that of legal relationships, and the difference is normally seen in various techniques employed to establish specific rights: by an act of the state and by a contract. [19, 281-282] It should therefore be concluded that encumbrances in private relationships are established by the free will of the parties concerned, while under public law encumbrances (those for the common good) are based on a law or regulation.

This division could remain purely theoretical if encumbrances had no different legal consequences. It should be stressed that contractual encumbrances (in civil relationships) may be cancelled or modified on the basis of the will of the parties concerned, while no such options are available with regard to encumbrances established by law (in public relationships). Consequently, the author cannot accept the opinion that there is no reason for perceiving public and private law as opposed. The equals sign placed between "public" and "private", on the one hand, and "forced and free system", "general benefit system and self-benefit system" or "public and individual area", on the other hand, does not compensate for the dogmatic dichotomy and, therefore, is likely to lead to considerable misunderstanding. [20,112]

The author believes that the absence of a clear procedure for appealing against decisions adopted by public authorities for owners whose properties are thereby encumbered is contrary to the principles of a democratic state.

The uncertainty of rightholders in whose favour encumbrances are created is inherent in the encumbrances established by public authorities. Encumbrances are made $a$ priori to satisfy the needs of society and for the common good. Society is represented by the government in relations with real estate owners and, therefore, these legal relationships are subject in full to the principles of public law. The Constitutional Court of the Republic of Latvia has held that "both the general principles of law and of public administration and the principles of spatial planning must serve as guidance for the proper and adequate exercise of discretion in the field of spatial planning" [21] and "in the course of the development of spatial (detail) plans, the local government must act as an unbiased and neutral mediator balancing the interests of the developer of a particular territory and the community concerned, hear and make an objective assessment of the opinions of all the parties involved regarding the most appropriate and suitable way of development of the particular territory, as well as comply with the requirements set out in spatial planning laws". [22]

The above means that whenever public authorities by their decisions cause impairment of property rights, these decisions must be particularly solid, lawful and proportionate. Based on the case-law of the European Court of Human Rights, researchers have concluded that restrictions must always be specific and set within clearly defined limits, with respect for the law (laws must be freely accessible, clearly formulated and understandable), public interests (spatial development, defence of democracy, elimination of consequences, protection of national financial interests, road construction, land reform, etc.) and proportionality (the balance between the interests of society and owners) [23, 319].

An objective assessment can only be made of the lawfulness of encumbrances, while public interests and the balance between the interests of society and owners can only be viewed on an individual basis. No uniform procedure for defining the scope of public interests and proportionality can be introduced because characteristics (the level of economic and social development of the community (populated location), development priorities and targets to be achieved, the type and extent of encumbrances) will always vary. Consequently, the competence of officials and their understanding of fundamental human rights and the ability of 
courts to ensure lawfulness and equality in disputes - these are factors that are of primary importance in maintaining social balance and justice.

The author classifies encumbrances depending on their form as follows:

1) operating prohibitions (restrictions);

2) prohibitions (restrictions) of the use of territories;

3) restrictions on the exercise of rights.

Operating prohibitions (restrictions) mean that in an encumbered territory the owner may not carry on certain economic activity or economic activities are allowed only to a limited extent and subject to special licences. For instance, no operations may be authorised in protection zones around water-supply points [16], and nature reserves may have areas where natural resources are fully excluded from economic or other activities. Limited economic activities may be allowed in certain areas of nature reserves [24], and operating restrictions are effective in forests during the breeding season. [25] It should be concluded that, in order to protect public interests, owners are prohibited from pursuing any profit-making activities which are associated with their properties but have environmental impacts, or are carried out in heritage sites, or involve facilities of public significance, or are performed during a certain period.

Encumbrances associated with the use of territories have similar substance. The only difference is that they are static by nature. A territory should be recognised as encumbered merely due to the existence of an encumbrance. These encumbrances include all kinds of protection zones which may not be used in any manner. In fact, these are territories excluded from civil transactions. Protection zones may have a width ranging from $1 \mathrm{~m}$ up to $300 \mathrm{~m}$. On certain occasions, considering the relation of the width of protection zones to the size of a property, the encumbered territory may be rather large, taking the major part of the property, thereby leading to a considerable decrease in the cadastral value. According to the State Land Service, the value of land may be down by $20 \%$ if the relevant property is located, for instance, in the dune protection zone of the Baltic Sea and the Gulf of Riga or in the territory of a cultural monument. [26] It should be concluded that encumbrances, which take the form of protection zones, not only prevent the owners from using certain part of their properties but also reduce the possibility of earning maximum benefits therefrom (i.e. sell at a higher price).

The third type of encumbrances provides for a special procedure for transactions. In the cases referred to in law, the owner of encumbered real estate is bound by pre-emptive rights granted to the state. Pursuant to Section 35(1) of the Law on Special Areas of Conservation, the state has a pre-emptive right to land located in nature conservation areas, nature reserves and natural monuments. [24] Hence, the owner of the land is not free to exercise his rights when choosing the buyer and he has to take into account the state as a rightholder and potential party to the transaction.

In conclusion, the establishment of encumbrances leads to a considerably narrower scope of an owner's property right, practically excluding the element of discretion, thereby reducing the possibility of obtaining economic benefits and restricting the freedom of transactions, which can be regarded as a substantial restriction of a fundamental right, i.e. the right to property. In view of the above, the author can only partially share the opinion expressed by Professor J. Peter Byrne that rights (also property rights) should not be evaluated from the viewpoint of precedence; instead, reasonable uniform requirements should be followed, stressing that legislative innovations affecting security interests do not destroy or restrict property, they change the rules and institutions within which the property system operates. Property measures, whatever their institutional form, should be evaluated on their capacities to enhance human welfare, including liberty and economic incentives. There are no barriers between the public and private dimensions of property. [27, 10] The opinion of Professor J. Peter Byrne can only be accepted if the state offered owners adequate compensation for encumbrances established with regard to their property for public needs.

Mechanisms offered by the state to minimise restrictions are essential to ensure compliance with the principle of proportionality. As the analysis of the Latvian legal system demonstrates, legislation provides for certain compensation only for one kind of encumbrances, i.e. operating restrictions, and it should be emphasised that this provision refers only to agriculture and forest management. [28] It should be added that in certain instances a land owner may demand repurchase of the land, and this right is in line with the mechanism intended to minimise the adverse effects to be faced by the owner. In view of the spread of protection zones and their effect on property rights of owners, the author takes a critical view of the law-giver's position whereby no compensation is provided for the establishment of protection zones. It is evident that legislation views only operating restrictions as encumbrances. This approach narrows the interpretation of encumbrances as a legal institution because any encumbrance (not only operating restrictions) may limit property rights of owners. Moreover, any encumbrance should be viewed in the context of proportionality. The author believes that the opinion given in scientific literature that property rights are relative and owners have obligations towards others is still questionable. The relevant obligations are more significant and are not merely limited to the avoidance of harm to others. Within their community, owners must share their property or benefits therefrom to maintain peace and social order $[29,234]$. The author criticises the form and manner of participation and society's contribution in response to encumbrances rather than the sharing requirement.

The owner makes it possible for the public to derive benefits from his property and, therefore, the owner has already fulfilled his obligations towards the public. The author is of the opinion that, without compensating for the restrictions caused by encumbrances, property rights of owners are restricted unreasonably and the balance between 
the duty to share a property to satisfy public needs and the right to property is destroyed.

\section{Conclusions}

An encumbrance should be understood as de facto and legal limitations imposed on real estate owned by private owners in the form of restrictions on the use of property and the special procedure for transactions, as may be necessary for public needs. In the case of encumbrances established within the frame of private relationships, i.e., based on an agreement between the parties, an owner's rights granted by property are not impaired substantially because such encumbrances are based on the will of the parties.

Major issues associated with the establishment of encumbrances can be observed in public relationships, namely in the case of encumbrances created by the state in public interests. An encumbrance is a way how private property may be used for public needs. Encumbrances have a legitimate goal and origin. Whenever encumbrances are established and maintained, the protection of property rights of owners by means of the effective legislation is not sufficient, nor is it commensurate with duties and restrictions imposed by encumbrances. These conclusions should be viewed in the context of the property right as a fundamental right. Although, according to literature, societal understandings of property have varied from culture to culture and from to time [30,40], both the value of property as a fundamental right and its content rendering the property right one of the most essential individual's rights have remained unchanged. The absence of legal mechanisms for individuals to affect the actual circumstances of an encumbrance established by the state for public needs by law and without compensation is strong evidence of the disproportionate safeguarding of individual's and public interests.

\section{Recommendations}

The improvement of the legislation governing encumbrances should be viewed in the context of the protection of owners' rights because the existing encumbrance regulation focuses on public interests. Property rights and mechanisms to ensure the exercise of these rights are primarily civil institutions to be considered in the development of legislation. For the purposes of proportionality, it is necessary to increase the participation of real estate owners in the creation of encumbrances.

With a view to ensuring the uniform legal treatment and rendering the establishment of encumbrances more transparent, it is desirable to consolidate laws governing encumbrances and introduce regulation whereby owners could initiate alteration or annulment of encumbrances under certain conditions. The legal nature of spatial planning is worthy of debate because limited possibilities of appeals testify to the misunderstanding of democracy.

\section{REFERENCES}

[1] Vispārējā Cilvēktiesību deklarācija. Available at: http://www.humanrights.lv/doc/vispaar/vispcd.htm, [viewed on 10.02.2015].

[2] Latvijas Republikas Satversme, adopted on 15.02.1922, entered into force on 07.11.1922. Published: Latvijas Vēstnesis, No 43, 01.07.1993.

[3] Hesselink, M.W. The New European Private Law: essays on the future of private law in Europe. Hague: Kluwer Law International, 2002, p. 283.

[4] Oliver D., Fedtke J. Human Rights and the Private Sphere the Scope of the Project. Grām: Human Rights and the Private Sphere. A Comparative Study. Ed. by Oliver D., Fedtke J. [B.v.], Routledge and Cavendish, 2007, p. 22.

[5] Torre M. Nostalgia for the Homogeneous Community: Karl Larenz and the National Socialist Theory of Contract. [B.v.]: European University Institute, 1993, p. 30-31.

[6] Civillikums. Trešā dal̦a. Lietu tiesības: Latvijas Republikas likums, adopted on 28.01.1937, entered into force on 01.09.1992. Published: Valdības Vēstnesis, No 44, 24.02.1937. Civillikums. Ceturtā daļa. Saistîbu tiesības: Latvijas Republikas likums, adopted on 28.01.1937, entered into force on 01.03.1993. Published: Zinotājs, No 1, 14.01.1993.

[7] Latvijas Republikas Augstākās tiesas Senāta Civillietu departamenta 2009. gada 12.augusta spriedums lietā SKC 192. Available at: http://at.gov.lv/lv/judikatura/judikaturasnolemumu-arhivs/senata-civillietu-departaments/klasifikator s-pec-lietu-kategorijam-ar-tezem/4-nolemumi-kas-izriet-no-1 ietu-tiesibam/45-servituti/ [viewed on 07.01.2016].

[8] Neilands, R. Labticīga hipotēkas ņēmēja aizsardzība. RSU 2014.gada 10.-11.aprị̣̄a konferences materiāli. Available at: http://www.rsu.lv/images/stories/zk2014/Labticiga_hipoteka s_nemeja_aizsardziba.pdf.

[9] Latvijas Republikas Augstākās tiesas Senāta Civillietu departamenta 2012. gada 25. aprị̣̄a SPRIEDUMS Lietā Nr. SKC-257/2012 http://at.gov.lv/lv/judikatura/judikaturas-nole mumu-arhivs/senata-civillietu-departaments/klasifikators-pe c-lietu-kategorijam-ar-tezem/4-nolemumi-kas-izriet-no-lietutiesibam/41-labticiga-ieguveja-aizsardziba/

[10] Vago, S., Nelson, A. Law and Society. Pearson Canada Inc, 2014, p. 22.

[11] Teritorijas attīstības plānošanas likums: Latvijas Republikas likums, adopted on 13.10.2011, entered into force on 01.12.2011. Published: Latvijas Vēstnesis, No 173, 02.11.2011.

[12] Latvijas Republikas Satversmes tiesas dati. Available at: $\mathrm{http}: / /$ www.satv.tiesa.gov.lv/?lang=1\&mid=19 [viewed on 10.02.2015].

[13] Latvijas Republikas Augstākās Tiesas Judikatūra. Tiesu prakses apkopojumi Administratīvajās tiesībās. 2013.gads Tiesu prakses apkopojums teritorijas plānošanas, būvniecības 
un vides lietās 2008 - 2012. Available at: http://at.gov.lv/lv/judikatura/tiesu-prakses-apkopojumi/admi nistrativajas-tiesibas/. [viewed on 10.02.2015].

[14] Zemesgrāmatu likums: Latvijas Republikas likums, adopted on 22.12.1937, entered into force on 05.04.1993. Published: Latvijas Vēstnesis, No 11, 08.04.1993.

[15] Latvijas Republikas Ministru kabineta noteikumi Nr.61, adopted on 04.02.2014, entered into force on: 13.02.2014. Published: Latvijas Vēstnesis No 31, 12.02.2014.

[16] Aizsargjoslu likums: Latvijas Republikas likums, adopted on 05.02.1997, entered into force on 11.03.1997. Published: Latvijas Vēstnesis No 56/57, 25.02.1997.

[17] Zvejniecības likums: Latvijas Republikas likums, adopted on 12.04.1995, entered into force on 12.05.1995. Published: Latvijas Vēstnesis No 66, 28.04.1995.

[18] Likums „Par kultūras pieminekḷu aizsardzību”: Latvijas Republikas likums, adopted on 12.02.1992, entered into force on 11.03.1992. Published: "Ziņotājs", 10, 05.03.1992.

[19] Kelsen H. Pure Theory of Law. Clark, New Jersey: The Lawbook Exchange Ltd. 2005.

[20] Bullinger M. Öffentliches Recht und Privatrecht. Stuttgart, Berlin, Köln, Mainz: W. Kohlhammer Verlag, 1968.

[21] Latvijas Republikas Satversmes tiesas 2004. gada 9. marta spriedums lietā Nr. 2003-16-05 5.punkts. Published: Latvijas Vēstnesis No 38, 10.03.2004.

[22] Latvijas Republikas Satversmes tiesas 2007. gada 28. novembra lēmums par tiesvedības izbeigšanu lietā $\mathrm{Nr}$. 2007-16-03 7.punkts. Published: Latvijas Vēstnesis No 194, 04.12 .2007 .
[23] Сагдеева, Л.В. Право на защиту собственности в актах Европейского Суда по правам человека. Москва, Статут, 2014. $319 \mathrm{c}$.

[24] Par īpaši aizsargājamām dabas teritorijām: Latvijas Republikas likums, adopted on 02.03.1993, entered into force on 07.04.1993. Published: Latvijas Vēstnesis No 5, 25.03.1993, Section 3(2).

[25] Meža likums: Latvijas Republikas likums, adopted on 24.02.2000, entered into force on 17.03.2000. Published: Latvijas Vēstnesis Nr.98/99, 16.03.2000, Section 37(4).

[26] Valsts Zemes dienesta informācija par kadastrālo vērtību ietekmējošiem apgrūtinājumiem. Available at: http://kadastralavertiba.lv/profesionali/vertibu-ietekmejosie-f aktori/apgrutinajumi/ [viewed on 12.02.2015].

[27] Byrne, J.P. The Public Nature of Property Rights and the Property Nature of Public Law. In: Malloy, R.P., Diamond, M. (eds.) The Public Nature of Private Property. Farnham, Surrey, England ; Burlington, VT: Ashgate, pp.1-12.

[28] Par kompensāciju par saimnieciskās darbības ierobežojumiem aizsargājamās teritorijās: Latvijas Republikas likums, adopted on 04.04.2013, entered into force on 01.06.2013. Published: Latvijas vēstnesis No 74, 17.04.2013.

[29] G. S. Alexander, E. M.Peñalver. An Introduction to Property theory, Cambridge University Press, 2012, p. 234.

[30] Diamond, M. Shared Equity Housing: Cultural Understanding and the Meaning of Ownership. In: Malloy, R.P., Diamond, M. eds. The Public Nature of Private Property. Farnham, Surrey, England; Burlington, VT: Ashgate, 2011, pp. 37-64. 